\title{
Reimagining Australian Nationhood: From Young Colony to Ancient Continent
}

\section{Zachary Hiam-Dibben}

University of Technology Sydney, Faculty of Arts and Social Sciences, PO Box 123, Ultimo NSW 2017, Australia. zachary.1.dibben@student.uts.edu.au

\section{DOI: https://doi.org/10.5130/nesais.v4i1.1534}

\begin{abstract}
Throughout its short history, colonial Australia has suffered from a severe anxiety surrounding its national identity. This essay argues that in limiting its selfhood to the virtues of its British settlers rather than foregrounding the customs of its Indigenous peoples, Australia is simply prolonging its crisis of identity.
\end{abstract}

Keywords: Australian national identity; settler colonialism; history wars; constitutional recognition

Australia's sense of national identity is rooted in European colonialism, completely disregarding Indigenous traditions, stories and culture. There is a significant limitation we as a nation have imposed upon ourselves by disregarding the Indigenous custodians. Australia strives to be an independent country, though at the same time has allowed all of its values to be an appropriation of British nationalism. The nation's identity leans so heavily on England that, to this day, the English monarchy still remains the head of state through the Governor-General. Mark McKenna (2018) proposes that the "true source of a more mature and independent Australia" is "the grounding of our sovereignty on our own soil, in the song lines and histories of an ancient island continent." What truly sets us apart from other Western counties is our vibrant Indigenous culture, whose history dates back over 65,000 years. As written in the Uluru Statement from the Heart, "With substantive constitutional change and structural reform, we believe this ancient sovereignty can shine through as a fuller expression of Australia's nationhood" (Council 2017). In order to achieve this true sense of unity as a nation, we must draw our attention to the inconsistencies of our dark history, free ourselves from the ideological shackles of colonialism, and create a platform on which the Indigenous population can stand with true agency.

Australia as a nation is not truly independent because it defines itself solely by the very limited recent history of British colonisation. Since its conception, Australia has suffered from a severe anxiety about its national identity. This self-consciousness has been aggressively repressed, especially in the 
way our history is interpreted. The Gallipoli landing, for example, is seen by many as the beginning of Australian history and a moment of true Australian autonomy, when in reality, this battle was carried out under the strict control of the British (McKay 2012). Many other moments in history are touted as the day of Australian independence, such as Captain Cook's landing, or the day of federation in 1901. However, these moments in history do nothing but exemplify the fact that Australia was never meant to be an independent country, but an extension of the British Empire. This is evident in the way our history has been used to selectively represent Australia's colonial past from a settler perspective. Described by Stanner as a "window, which has been carefully placed to exclude a whole quadrant of the landscape" (1969, p. 24), this distortion of history has seen the Indigenous population hidden from the public sphere in a "cult of forgetfulness practiced on a national scale" (1969, pp. 24-25). This selective historical lens is used primarily as a tool to incite nationalism, or rather, to define a very particular kind of Australia that excludes non-white voices. As argued by Barry Morris (1989, pp. 67), colonialism is a "cultural process" that operates through "political conquest and economic exploitation." As a result, the voices on the other side of the frontier are silenced, and we are left with a culture comprised entirely of the enforced virtues of the colonisers. To this day, Australia's dark colonial history has been concealed in an attempt to distance itself from these events and create a less sinister identity. This has had the reverse effect, causing the nation to continue the same mistakes in the present, and further alienate the Indigenous population. Some of the most severe massacres against Indigenous people were driven by global capitalist demand for the cattle and wool industries (Goodall 1995, pp. 62-70). These are moments in our history that we have collectively ignored; yet, in the present, the same factors continue to overturn Indigenous land ownership. Our values as a nation are forged in the moments of history that we deem worthy of remembering. In this sense, Australia has limited its identity to the virtues of colonialism, partly to escape the shame of our dark history, in a way that ultimately reinforces its continuation through Western modernity.

While it is commonly misconstrued that Australia lacks a proper identity because it is simply too young, it is in fact an ancient land, rich with Indigenous knowledge and antiquity that can serve as a backbone to a truly unified nation. Despite what the lingering colonialist view of Australia as 'Terra Nullius' would have us believe, the Indigenous custodians prior to colonisation utilised the land in extraordinary ways, with a legitimate form of society that should not be disregarded. As outlined by historical researcher Heather Goodall, Aboriginal societies had developed many forms of land management that effectively harvested natural resources in a sustainable way. Some strategies included: utilising grass pastures with firestick farming to store seed and maintain a population of hunting game; and executing complex engineering techniques such as the creation of large fish traps that could be used to harvest fish all year long, supporting a population of 750,000 people (1995, pp. 61-62). The Indigenous knowledge of the land is so extraordinary that their methods have been crudely appropriated by white Australia. For example, it is estimated that over the course of 12 months, 500,000 tons of greenhouse gas emissions are avoided when allowing Indigenous Australians to control burn management of the environment (Korff 2018). Here it is clear that ancient Indigenous knowledge has concrete, pragmatic appliances to the maintenance of Australian land. This effectiveness can also be observed in the many forms of Indigenous spirituality and culture that have persisted throughout history. Heather Goodall $(1995$, p. 62) points out that despite the huge amount of varying Indigenous language groups across the country, there is "no evidence of widespread or endemic warfare among these societies" and that they were in fact "linked with many trading networks" that were "channels of dynamic cultural and economic exchange, displayed most 
spectacularly in regular, large ceremonial meetings." This clearly demonstrates the uniting power of Indigenous culture and spirituality, a quality that Australia desperately requires to break away from the colonial shackles and become an independent, unique nation.

While Australia's colonial history has far too much influence over our sense of nationhood, it still has a significant role to play in bridging the gap between settlers and Indigenous Australians. Historians Gillen and Ghosh (2007, p. 177) argue that because "regimes and ideologies of imperialism transformed the cultures, knowledge, life-worlds and life-practices of both settlers and natives, the possibilities of dialogue may proceed from these shared experiences." This methodology can be applied to the heated political climate in Australia today, in which many white Australians feel that they are labelled as the colonial oppressor based on a history and culture they inherited. The burden of history is, in fact, something that hangs over all Australians, irrespective of race or class. Uniting as a nation and identifying these anxieties is the first step in establishing a new set of values, as our dark history can inform our forward momentum into a more cohesive Australia. This process, however, has proven extremely difficult due to the government's desire to manipulate the way Australian history is interpreted to protect the current model of Australian nationalism. The role of historians in this process is to establish the larger truths of our history, as well as challenge uncritical conclusions about the past (Read 2002, p. 60). In addition, individual Australians must stand their ground when they discover truths that contradict with our current national narrative. Goodall states that the most successful reconciliation processes take place where there is "space for reflection and ambiguity, reevaluation and complexity" (2002, p. 21). While the Federal Government has set out its conclusions before evaluation of the past has begun, the most productive path is to approach our colonial past with a sense of shared ambiguity of what will be drawn from the truth. This shared experience will unite Indigenous and non-Indigenous Australians as we construct our values together.

Perhaps the most integral part of this re-evaluation of history is the way in which the next generation of Australians are educated. Ray Land (1994, p. 8) argues that the current curriculum on Australian history is controlled by "colonial conquest" that works through "systematic inclusion and exclusion of certain interests and perspectives, for representation of some actors at the expense of others and to control professional educators through selective government intervention and policy making processes." This approach to education is very limited, as it excludes the knowledge and perspectives of the oppressed in favour of the oppressors, whom have recorded events from a dated Darwinist viewpoint. For example, the early settlers didn't consider the landing in Australia to be an invasion, which has persisted as the dominant narrative in the present day. This has influenced the general public to accept the outdated ideology that the Aboriginal people were not civilised enough to claim land ownership. However, this is not to say that the European perspective should be disregarded altogether. In fact, in her studies of the student engagement of Australian history, Anna Clark (2008, pp. 86-88) found that while students have lost interest in the limited and repetitive means in which Australian history has been taught, the act of confronting the different perspectives and exploring the contested nature of the past has in fact resulted in high student engagement. In order for the skewed collective memory to be corrected, the curriculum must include the many stories and experiences of people from both sides of the colonial frontier and highlight their contradictory nature, encouraging students to engage with the topic and draw their own balanced conclusions. With Australia's future generations engaging with history from this vantage point, a new, more grounded sense of national identity will emerge. 
In order for Australia to fully realise itself as an independent nation, it will not only require a reevaluation of the past, but also a serious shift in the influence of Indigenous voices in its Constitution and society as a whole. Neol Pearson (2014, p. 71) states that "you cannot have a unified nation, this cannot be a fair nation, without the proper inclusion of that 3 per cent of the nation who were originally excluded from the Constitution." One integral component already acquired by the 1967 Referendum is the ability to pass laws that specifically concern Indigenous Australians. Currently, Indigenous Australians have the cards stacked against them as a result of our colonial history, with a disproportionate number of Indigenous people living in poverty and incarceration. This is unlikely to change under the current climate, and in order to allow Indigenous custodians equal access to the human rights that other Australians enjoy, it is crucial to "allow for special measures that discriminate in favour of a disadvantaged group, but these measures must be temporary or the fabric of human rights law and principle is breached" (Langton 2013, p. 17).

However, this has been ineffective in achieving equality due to the fact that primarily white politicians, who lack firsthand experience in Indigenous oppression, have made these decisions. What is required here is an inclusion of Indigenous voices in parliament, allowing them to have autonomy and the dignified power to make decisions about their future in their own nation. With this in mind, the validity of Indigenous land rights would no longer be determined by Western standards of proper land use. The changes in the Constitution would also need to move away from sovereignty under the Commonwealth, and a grounding of national values under the traditions and histories of Indigenous culture. Too long have Aboriginal people been subject to cultural exclusion, seen as 'the other' to the white norm that defines Australia. Historian Charles Taylor (1997, p. 26) suggests that Indigenous Australians have been subject to a distorted version of their own identify, defined by their difference from the colonial norm, that serves only to further imprison them. Even with the affirmative action in policy suggested, this exclusion would limit their ability to take advantage of avenues made available. It is commonly suggested that in order to overcome this, Indigenous Australians should disregard their heritage and assimilate into Western culture. However, Indigenous Australians define themselves by "their identity as a people, their territories, their cultural heritage and their language" (Pearson 2014, p. 55). To suppress this is nothing less than genocide. It would be more productive for white Australia to instead assimilate into Indigenous culture, to sever ties with colonial virtues and seek meaning under the guidance of the original custodians. Indigenous Australians should not simply be allowed to participate in the Australian way of life, but rather they should be granted the power to define our vision of Australia's popular sovereignty.

From this discussion it is evident that Australia requires a serious shift away from the colonial histories and virtues used to define its independence as a nation. In order to develop a truly authentic identity, the voices of Indigenous custodians must be brought to the forefront and be given the agency to help define our national sovereignty. As stated by philosopher George Santayana (2014, p. 92), "those who cannot remember the past are condemned to repeat it." Moving forward as a truly independent nation, we must collectively acknowledge the effects of our colonial past in the present day and consider how the many untold stories of this ancient island continent can bring about a true sense of nationhood. 


\section{References}

Clark, A. 2008, History's children: History wars in the classroom, Sydney, UNSW Press, pp. 86-88.

Council, R. 2017, Uluru statement from the heart.

Gillen, P. \& Ghosh, D. 2007, 'Race', Colonialism and modernity, UNSW Press, p. 177.

Goodall, H. 1995, 'New South Wales' in A. McGrath (ed) Contested ground: Australian Aborigines under the British crown, St Leonards, NSW: Allen \& Unwin, pp. 61-70.

Goodall, H. 2002, “Too early or not soon enough? Reflections on 'sharing' histories as process not collection”, Australian historical studies, Vol. 33, No. 118, p. 21.

https://doi.org/10.1080/10314610208596176

Korff, J. 2018, Creative spirits, viewed 16 June 2018, $<$ https://www.creativespirits.info/aboriginalculture/land/aboriginal-fire-management>.

Land, R. 1994, "Furore over invasion text": Introduction to the politics process and players', Invasion and after: A case study in curriculum politics, Griffith University: Queensland Studies Centre, p. 8.

Langton, M. 2013, 'Indigenous exceptionalism and the constitutional 'race power', Published in Space and Culture, p. 17.

Langton, M. 2013, "Indigenous exceptionalism and the constitutional 'race power', Space, Place and Culture, p. 17.

McKay, J. 2012, 'A critique of the militarization of Australian history and culture thesis: The case of Anzac battlefield tourism', PORTAL Journal of Multidisciplinary International Studies, vol. 10, no. 1.

McKenna, M. 2018, 'Moment of truth: history and Australia's future', Quarterly essay, issue 69.

Morris, B. 1989, 'Domesticating resistance: the Dhan-gadi', Aborigines and the Australian state, Vol. 3, Bloomsbury Academic, pp. 6-7.

Pearson, N. 2014, A Rightful Place, Quarterly Essay 55, pp. 55-71.

Read, P. 2002, 'Clio or Janus? Historians and the stolen generations', Australian historical studies, vol. 33, no. 118, p. 60. https://doi.org/10.1080/10314610208596179

Santayana, G. 2014, The life of reason or the phases of human progress: Reason in religion, vol. 7 , no. 3, Mit Press, p. 92.

Stanner, WEH, 1969, 'The great Australian silence', The 1968 Boyer lectures: after the dreaming, Sydney, ABC Enterprises, p. 24-25.

Taylor, C. 1997, 'The politics of recognition', Multiculturalism and the politics of recognition: An essay, Princeton University Press, p. 26. 
NEW: Emerging scholars in Australian Indigenous Studies 2018

(c) (i) (C) 2018 by the author(s). This article is distributed under the terms and conditions of the Creative Commons Attribution license (http://creativecommons.org/licenses/by-nd/4.0/). 